\title{
Phytochemical analysis and antioxidant activity of leaf extracts of some selected plants of the family Acanthaceae
}

\author{
Kshetrimayum Kripasana \& Jobi Xavier* \\ Department of Life Sciences, CHRIST (Deemed to be University), Bengaluru 560 029, India \\ *Email:frjobi.xavier@christuniversity.in
}

\section{ARTICLE HISTORY}

Received: 30 December 2019

Accepted: 09 February 2020

Published: 04 May 2020

\section{KEYWORDS}

Phytochemistry

Ethnopharmacology

Antioxidant

Quantitative analysis

DPPH

\section{ABSTRACT}

The present era of scientific research has witnessed an enumerable amount of evidences to showcase the immense potential of medicinal plants. In the present investigation, the phytochemical analysis of Phlogacanthus pubinervius T. Anderson., Adhatoda vasica (L.) Nees, Phlogacanthus thyrsiflorus Nees, Phlogacanthus curviflorus (Wall.) Nees, and Ruellia tuberosa L. was carried out for the different plants extracted with methanol. Analysis was carried out to estimate the quantity of phenols, carbohydrates, tannins, flavonoids and proteins. The antioxidant property of these plants were analysed using DPPH method. The concentration of the plant samples required to decrease the DPPH concentration by $50 \%$ was calculated by interpolation from linear regression analysis and denoted $\mathrm{IC}_{50}$ value $(\mu \mathrm{g} / \mathrm{ml})$. The qualitative analysis showed the presence of alkaloids, tannins, saponins, proteins, carbohydrate and phenols in all the sample extracts. The highest amount of tannins and phenols was observed in $P$. thyrsiflorus. P. pubinervius (77.83\%), A. vasica (74.81\%), P. curviflorus $(94.20 \%)$, and R. tuberosa $(70.78 \%)$ which showed highest antioxidant activity of DPPH-scavenging at $150 \mu \mathrm{g} / \mathrm{ml}$ of methanol extract. The high percent of scavenging activities of those plants add value to their medicinal properties. The presence of the high amount of phytochemical compounds suggests that the plants have high amount of medicinal compounds and can be extensively used to extract the natural compounds.

\section{Introduction}

People started to use plant extracts as medicines in many of the traditional practices. Ethnopharmacology, one of the areas of Ethnobotany, is considered the scientific evaluation of traditional medicinal plants. It was suggested that ethnomediated samples were succeeded to identify the drugs in the treatment of different ailments like gastrointestinal, inflammatory and dermatological complaints. Plant and animal products produced by different organisms have been isolated and characterized as biologically active compounds (1).

Phlogacanthus thyrsiflorus is considered to be a sacred plant in Manipur and in most of the northeastern states of India. $P$. thyrsiflorus will usually grow up to $2.4 \mathrm{~m}$, quadrangular stem, leaves of 13 to $35 \mathrm{~cm}$ long and oblanceolate, elliptic or oblong, acute or acuminate, and entire. Flowers are found in terminal elongated thyrsus. Adhatoda vasica is a common plant found in different gardens. However, the other two species, i.e., Phlogacanthus pubinervius and Phlogacanthus curviflorus are mainly forest plants and also found in wastelands. Ruellia tuberosa is found in the garden; but it is grown commonly as ornamental for its purple flower. $P$. pubinervius, an evergreen perennial shrub, is found to be very coloured in spring with its densely packed red-tubular flowers in its upright spike inflorescence. This shrub may grow up to $3 \mathrm{~m}$ tall, with quadrangular stem sand drooping leaves. $P$. curviflorus is a shrub, stems branched and grows up to 3-4 $\mathrm{m}$ tall. Leaves are arranged in opposite phyllotaxy and 8-9 inches long; flowers are borne on spike inflorescence at the end of the branches. Flowers are showy, tubular and reddish in colour. $R$. tuberosa is an erect, sub-erect or diffuse perennial herb which grows up to 60-70 cm tall, with four-angled stems, swollen and purplish at the nodes,

(C) Kripasana \& Xavier (2020). This is an open-access article distributed under the terms of the Creative Commons Attribution License, which permits unrestricted use, distribution, and reproduction in any medium, provided the original author and source are credited (https://creativecommons.org/licenses/by/4.0/).

To cite this article: Kripasana K, Xavier J..Phytochemical analysis and antioxidant activity of leaf extracts of some selected plants of the family Acanthaceae Plant Science Today. 2020;7(2):264-274. https://doi.org/10.14719/pst.2020.7.2.717 
and hairy. Roots are very slender, elongated, tuberous and white in colour. Leaves are used as liquid drink to cure gonorrhoea and ear diseases (2).

Boiled leaves of $P$. pubinervius are used to cure cough, cold, and asthma. A. vasica is used as a remedy for the treatment of cold, cough, chronic bronchitis and asthma (3). The principal active compounds found in $A$. vasica include alkaloids like vasicine and vasicinone. The vasicine is used as a herbal drug in India, as they are the derivatives of alkaloids, bromhexine and ambroxol (4). Another property of this herb is that it stops bleeding. All parts of this plant are used for the extraction of volatile oils and alkaloids, which show high medicinal properties $(5,6)$. The people use flowers of $P$. thyrsiflorus as vegetables. It shows antimicrobial properties. Fruits and leaves are used in the treatment of fever (7). In Manipur, boiled leaves of $P$. curviflorus are used as a remedy for cough and fever. Flowers are taken raw as a tonic. In Arunachal Pradesh, the people use the flowers as a condimental food. The young leaves and flowers of $P$. curviflorus var. menchanens are consumed as a vegetable by the people of Manipur (8). R. tuberosa is considered to be containing medicinal compounds that helps in stomach cancer. The dried root powder of the plant is reported to have the effect of causing abortion, and the decoction of leaves is used in treatment of bronchitis (9).

The present study also focussed on the properties of the antioxidant activities of the leaf extracts of the selected plants. As we know that in every living cell, oxygen is essential for the survival of all on this earth. Survival of life is not possible without oxygen. During the process of oxygen utilization in a normal physiological and metabolic process, approximately $5 \%$ of oxygen as per study gets univalently reduced to oxygen derived free radicals like superoxide, hydrogen peroxide, hydroxyl and nitric oxide radicals. All these radicals are known as reactive oxygen species (ROS) that exert oxidative stress towards the cells of human body rendering each cell to face about 10000 oxidative hits per second. In general, the effect of antioxidants is to break up the chains formed during the propagation process by providing a hydrogen atom or an electron to quench the free radical and receiving the excess energy possessed by the activated molecule (10).

The objective of the present study was to compare the phytochemical compounds present in the selected members of the family Acanthaceae. We also focussed on the quantification of bioactive compounds found in the plants. The study was also aimed at evaluating the antioxidant properties of the selected plants.

\section{Materials and Methods}

\section{Collection of plant samples}

Fresh and healthy plant parts of $P$. pubinervius and $P$. thyrsiflorus were collected in sterile polythene bags from Imphal east district called Tabungkhok in Manipur. P. curviflorus leaves were collected from
Luwangsangbam near Matai Garden. R. tuberosa and $A$. vasica flower, stem and leaves were collected from Tabungkhok and Yaiskul of Imphal West. Collected plant parts were examined, identified and kept for experimental use in CHRIST (Deemed to be University) Botany laboratory.

\section{Preparation of solvent extract}

The cleaned, healthy plant materials were cut into small sections and dried under shade for a few days and then dried in a hot air oven. The dried materials were ground into a fine powder. The powder obtained was stored in a desiccator and kept in room temperature for extraction. The methanolic extracts of the samples were prepared by $2 \mathrm{~g}$ of dried powder in $20 \mathrm{ml}$ of solvent. The extracts were filtered using filter paper. The extracts were tested for detecting various compounds such as flavonoids, tannins, saponins, protein, phenol, carbohydrates, etc. For quantification analysis, $5 \mathrm{~g}$ of the sample was extracted with methanol using soxhlet apparatus. The extracts were evaporated using a rotary evaporator (10).

\section{Phytochemical analysis of plants extract}

The preliminary phytochemical compounds were analysed using the filtered leaf extracts of the plants following the standard procedure (10).

Table 1. Qualitative phytochemical results of leaf extracts of different plant samples

\begin{tabular}{|c|c|c|c|c|c|}
\hline $\begin{array}{l}\text { Chemical } \\
\text { compounds }\end{array}$ & $\underset{1^{\mathrm{a}}}{\text { Sample }}$ & $\begin{array}{c}\text { Sample } \\
2^{\mathrm{b}}\end{array}$ & $\begin{array}{c}\text { Sample } \\
3^{c}\end{array}$ & $\underset{4^{\mathrm{d}}}{\text { Sample }}$ & $\begin{array}{c}\text { Sample } \\
5^{\mathrm{e}}\end{array}$ \\
\hline Alkaloids & ++ & ++ & ++ & ++ & ++ \\
\hline Flavonoids & + & ++ & ++ & + & + \\
\hline Tannins & ++ & + & ++ & ++ & + \\
\hline Phenols & ++ & ++ & ++ & ++ & ++ \\
\hline Proteins & ++ & + & ++ & ++ & - \\
\hline Terpenoids & ++ & + & ++ & ++ & + \\
\hline Saponins & ++ & ++ & ++ & ++ & + \\
\hline Carbohydrates & ++ & ++ & + & ++ & ++ \\
\hline
\end{tabular}

\section{Estimation of tannin content (TC)}

Tannin content was estimated using Folin-Ciocalteu's assay (11). To $0.2 \mathrm{ml}$ of the extract, $0.5 \mathrm{ml}$ of the FolinCiocalteu's reagent was mixed and then $2 \mathrm{ml}$ of sodium bicarbonate solution $[20 \%(\mathrm{w} / \mathrm{v})]$ was added slowly by stirring to the mixture and incubated for 2 $\mathrm{h}$ in dark at room temperature and the absorbance was measured at $725 \mathrm{~nm}$. For quantification of the TC content in the sample, a standard calibration curve was plotted using Tannic acid (11).

\section{Estimation of phenol content}

The amount of phenol was determined by the slightly modified Folin and Ciocalteu method (11). To $200 \mu \mathrm{l}$ of the sample extract, the volume was made up to $3 \mathrm{ml}$ with distilled water, $0.5 \mathrm{ml}$ of Folin Ciocalteu reagent mixture and $2 \mathrm{ml}$ of $20 \%$ sodium carbonate were added. The solution was mixed thoroughly and for one min kept on boiling water bath, cooled and measured absorbance at $638 \mathrm{~nm}$. Catechol dilutions were used as standard solutions. The results of phenols were expressed in terms of $\mathrm{mg} / \mathrm{ml}$ of extract. 


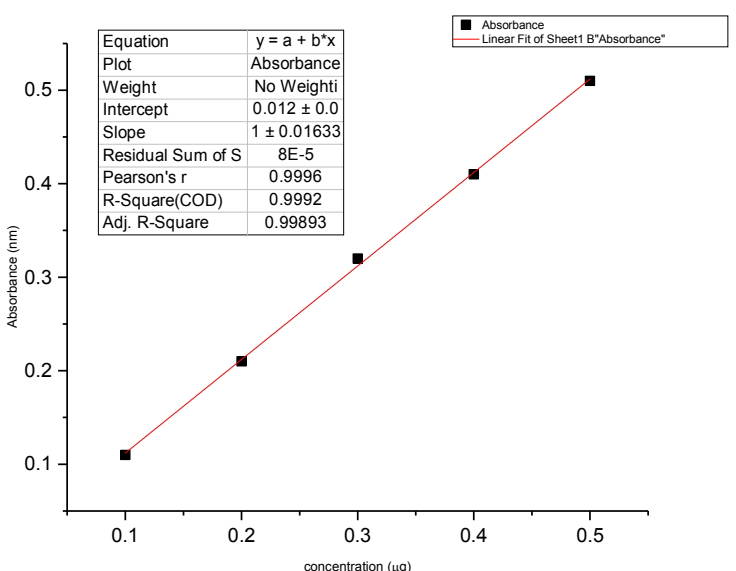

Fig. 1. Standard graph of Tannins at $725 \mathrm{~nm}$ wavelength using tannic acid in $\mu \mathrm{g} / \mathrm{ml}$.

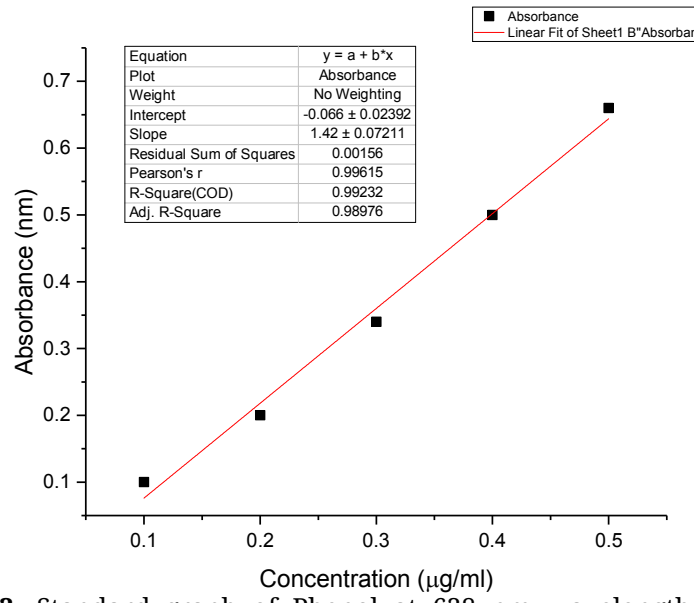

Fig. 3. Standard graph of Phenol at $638 \mathrm{~nm}$ wavelength using catechol in $\mu \mathrm{g} / \mathrm{ml}$.

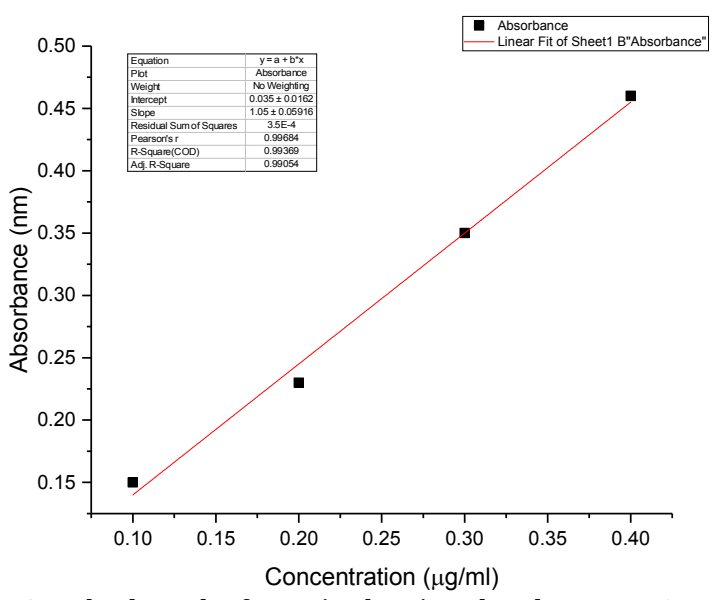

Fig. 5. Standard graph of protein showing absorbance at $595 \mathrm{~nm}$ using BSA $\mu \mathrm{g} / \mathrm{ml}$.

\section{Estimation of protein content}

The total protein content was determined by using Bradford's method (12). To $100 \mu \mathrm{l}$ of the sample extract, $3 \mathrm{ml}$ of Bradford's reagent was added and incubated in the dark for $5 \mathrm{~min}$. The absorbance was measured at $595 \mathrm{~nm}$. Bovine serum albumin dilutions ( 0.1 to $0.5 \mathrm{mg} / \mathrm{ml}$ ) were used as standard solutions.

\section{Estimation of carbohydrate content}

Phenol sulphuric acid method was used in which, 0.1 g sample was vortexed with $5 \mathrm{ml}$ of $2.5 \mathrm{~N} \mathrm{HCl}$, placed the test tube in boiling water bath for $3 \mathrm{~h}$, and cooled to room temperature. It was then neutralised with

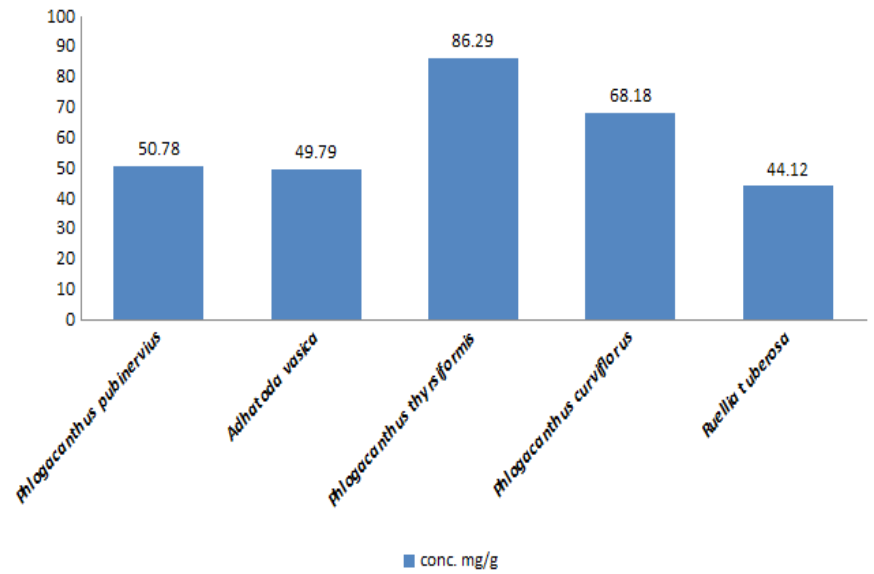

Fig. 2. The concentrations of tannins present in different plant samples.

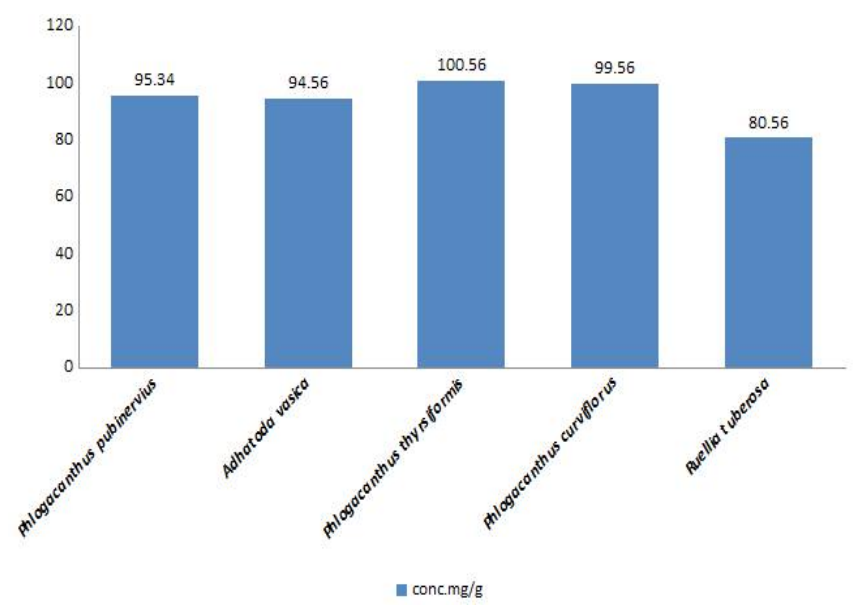

Fig. 4. Graphs showing the amount of phenol content $(\mathrm{mg} / \mathrm{g})$ in different plant samples.

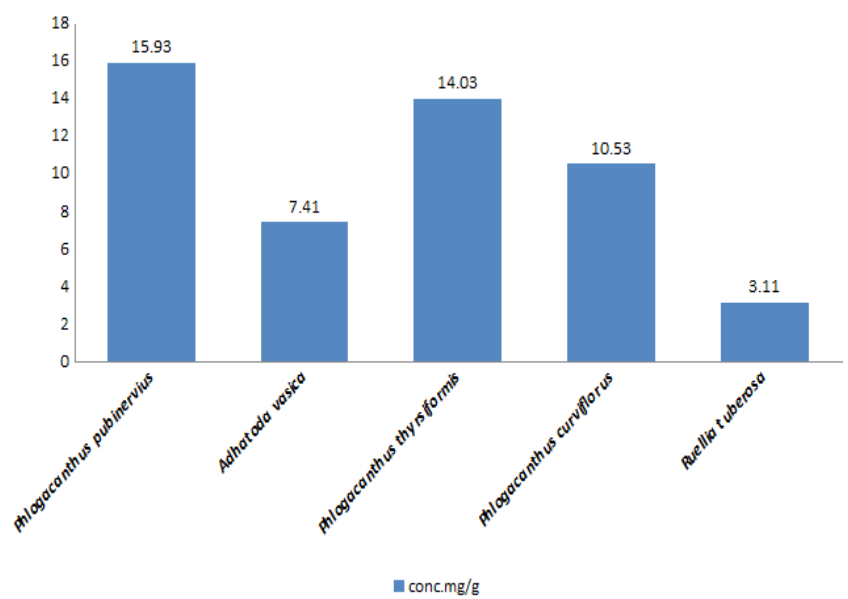

Fig. 6. Graph showing the amounts of protein content in different plant samples

$\mathrm{Na}_{2} \mathrm{CO}_{3}$ until effervescence ceased. Volume was made up to $100 \mathrm{ml}$, centrifuged in $10000 \mathrm{rpm}$ for $10 \mathrm{~min}$ and $0.2 \mathrm{ml}$ of sample solution, made up to $1 \mathrm{ml}$, was kept in two separate tubes. Then, $1 \mathrm{ml}$ phenol was added followed by $5 \mathrm{ml}$ of $96 \%$ sulphuric acid and shaken well. After $10 \mathrm{~min}$ it was placed in a water bath at $25-30{ }^{\circ} \mathrm{C}$ for $20 \mathrm{~min}$ and absorbance was read at $490 \mathrm{~nm}(12)$.

\section{Estimation of flavonoid content}

The flavonoid content of each sample was carried out using the method described by Chang et al. (13). In $100 \mu \mathrm{l}$ of plant sample extract, $1.5 \mathrm{ml}$ of ethanol was added and was mixed thoroughly, $100 \mu \mathrm{l}$ of $1 \mathrm{M}$ 

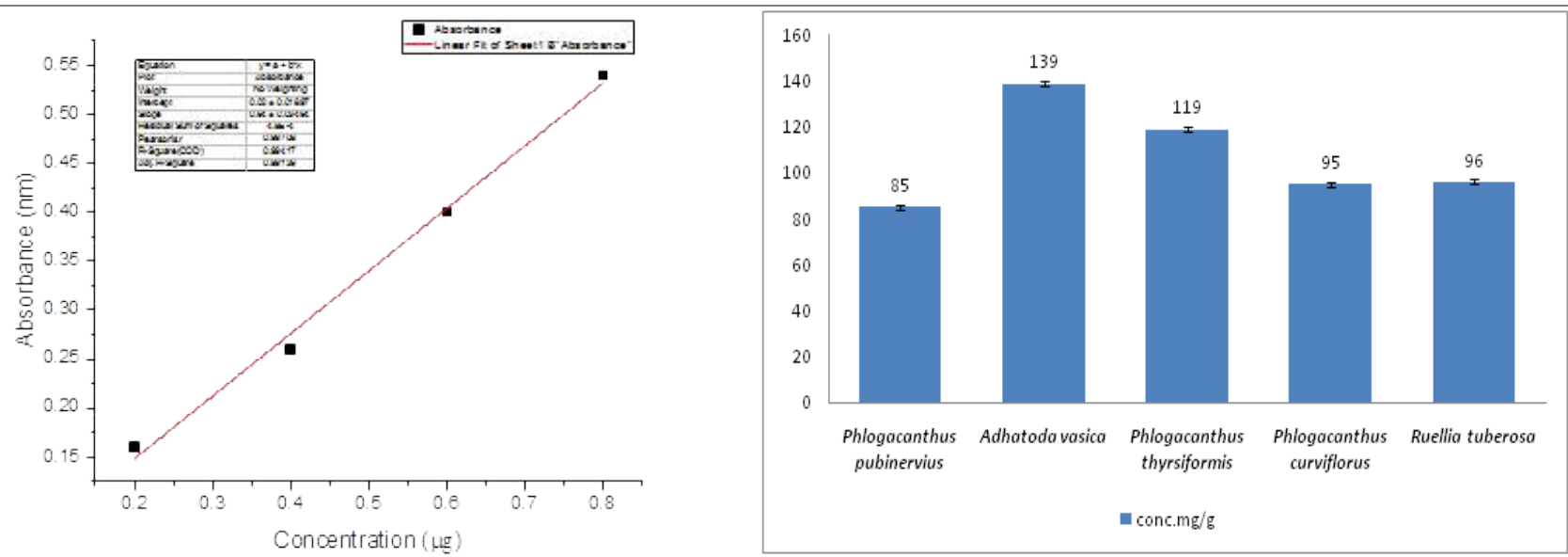

Fig. 7. Standard graph showing carbohydrates concentration using Fig. 8. Graphs showing different amounts of carbohydrates in glucose in $\mathrm{mg} / \mathrm{ml}$.

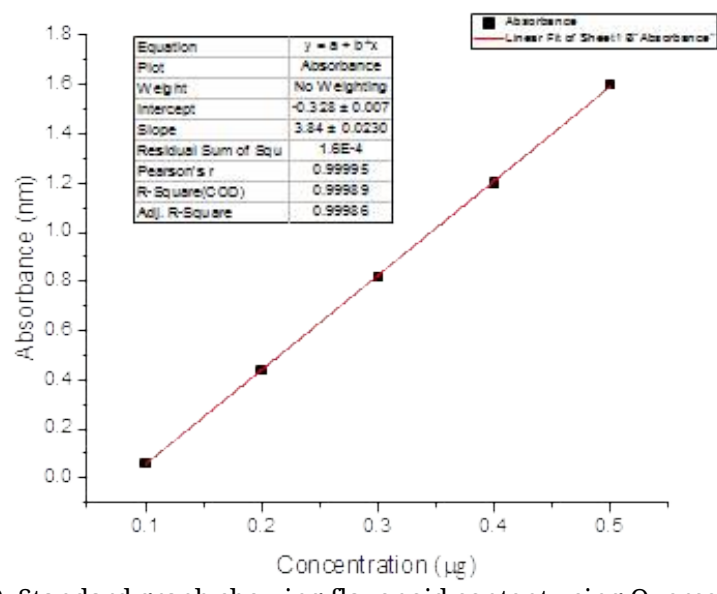

Fig. 9. Standard graph showing flavonoid content using Quercetin $\mu \mathrm{g} / \mathrm{ml}$.

potassium acetate was added, and $2 \mathrm{ml}$ distilled water, the tubes were kept at room temperature for $40 \mathrm{~min}$ and read absorbance at $415 \mathrm{~nm}$. Quercetin was used as the standard in a range of 2-10 $\mu \mathrm{g}$.

\section{GC-MS (Gas Chromatography - Mass Spectrometry) analysis}

GC-MS analysis was carried out on a Shimadzu single quadrupole GCMS-QP2010SE gas chromatographmass spectrometer (USA) which includes an Auto sampler and a Quadrupole mass analyzer: The column used was SH-Rxi ${ }^{\mathrm{TM}}$-5Sil MS- Low-polarity phase: Crossbond ${ }^{\mathrm{TM}}$ silarylene phase 1,4-bis (dimethylsiloxy) phenylene dimethyl polysiloxane ID: $0.25 \mathrm{~mm}$ df: $0.25 \mu \mathrm{m}$ Lenght: $30 \mathrm{~m}$ (Similar phases: DB-5ms UI, DB-5ms, VF-5ms, SLB-5ms) The carrier gas used was Helium at a flow rate of $1 \mathrm{ml} / \mathrm{min}$.

\section{Antioxidant activity using DPPH assay}

Antioxidant activity was measured using DPPH radical-scavenging activity assay (14). Stock solution (1 $\mathrm{mg} / \mathrm{ml}$ ) diluted to dilutions series of 100-150-250 $\mu \mathrm{g} / \mathrm{ml}$ with respect to solvent methanol. To an aliquot of each dilution, $3 \mathrm{ml}$ of a methanolic solution of DPPH was mixed thoroughly. Mixtures were shaken well and then incubated at $37{ }^{\circ} \mathrm{C}$ in the dark for 30 min. The control contained $3 \mathrm{ml}(\mathrm{v} / \mathrm{v})$ methanol $(1 \mathrm{ml})$ and methanolic solution of DPPH. The absorbance was measured at $517 \mathrm{~nm}$ against methanol blank.

Percentage of DPPH scavenging was calculated as: different plant samples.

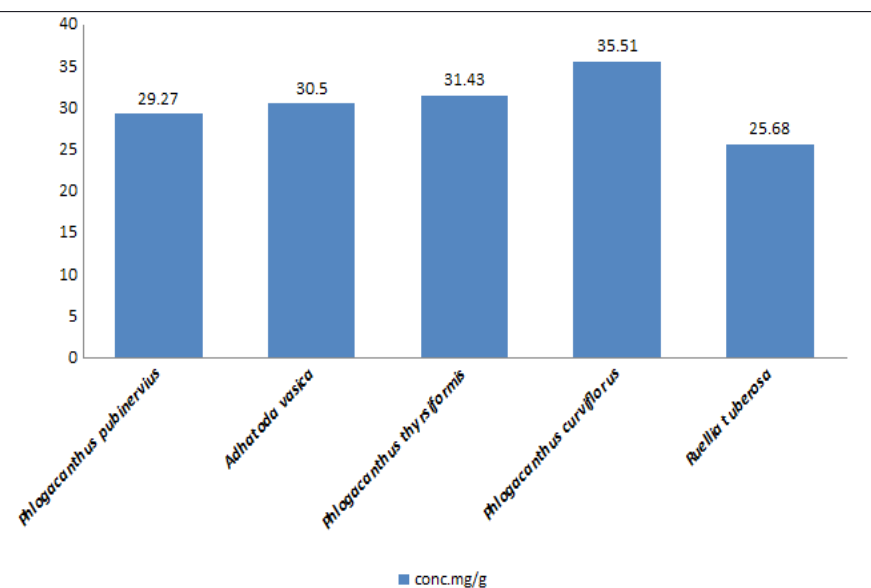

Fig. 10. Graphs showing the flavonoid content in different plant samples of crude extract.

DPPH radical scavenging activity $(\%)=[($ Abs controlAbs sample)/Abs control] x 100

\section{Results}

\section{Preliminary phytochemical analysis \\ Estimation of tannin}

Tannins were present in all the samples extracted by methanol. More amount of tannins was present in $P$. thyrsiflorus, i.e., $86.298 \pm 0.707 \mathrm{mg} / \mathrm{g}$ of crude extract. The less amount of tannins was observed in $R$. tuberosa, i.e., $44.121 \pm 0.389 \mathrm{mg} / \mathrm{g}$ of crude extract of plant sample (Fig. 1, 2).

\section{Estimation of phenol}

Concentration of phenol was estimated using catechol as the standard (Fig. 3). The highest amount of phenol was present in $P$. thyrsiflorus (100.56 \pm 0.94 $\mathrm{mg} / \mathrm{g}$ ) while the lowest amount was observed in $R$. tuberosa (80.56 $\pm 0.46 \mathrm{mg} / \mathrm{g}$ ) (Fig. 4).

\section{Estimation of protein}

The protein present in the plants selected was measured at $595 \mathrm{~nm}$ absorbance. The highest amount of protein was present in P. pubinervius of $15.934 \pm$ $0.213 \mathrm{mg}$ in $1 \mathrm{~g}$ of plant sample while the lowest amount of protein in $R$. tuberosa with $3.113 \pm 0.08 \mathrm{mg}$ in $1 \mathrm{~g}$ of plant sample taken (Fig. 5, 6). 


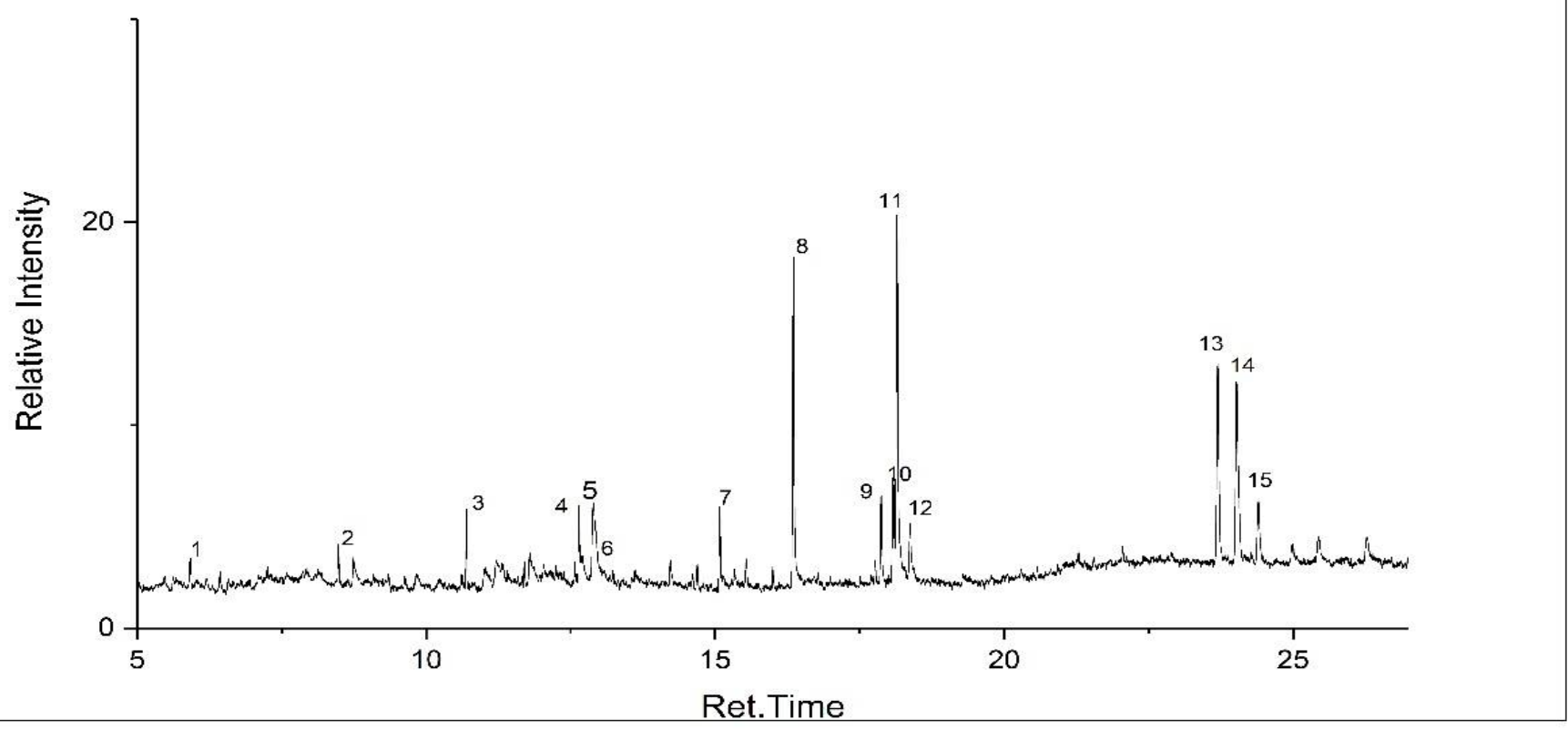

Fig. 11. GC-MS chromatogram of Phlogacanthus thyrsiflorus. The phytochemical compounds identified in the methanolic extract in GC-MS is given in Table 2 with respect to the peaks.

Table 2. Compounds identified in the methanolic leaf extract of Phlogacanthus thyrsiflorus in GC-MS

\begin{tabular}{cccl}
\hline Peak\# & R.Time & Area & Name \\
\hline 1 & 3.788 & 54.82 & 2-Ethylhexane \\
\hline 2 & 5.919 & 0.65 & Decade \\
\hline 3 & 8.484 & 0.53 & Dodecane \\
\hline 4 & 10.698 & 1.15 & Tetradecane \\
\hline 5 & 12.646 & 1.06 & Nonadecane \\
\hline 6 & 12.894 & 3.00 & Hexanoic acid, 2-ethythexyl ester \\
\hline 7 & 12.945 & 0.55 & 2,4-Dimethyl-3-hexanone \\
\hline 8 & 15.083 & 1.48 & Neophytadiene \\
\hline 9 & 16.354 & 6.45 & n-Hexadecanoic acid \\
\hline 10 & 17.873 & 1.97 & Phytol \\
\hline 11 & 18.081 & 2.48 & Linoelaidic acid \\
\hline 12 & 18.147 & 9.48 & 9,12,15-Octadecatrienoic acid, (Z,Z,Z)- \\
\hline 13 & 18.373 & 1.08 & Octadecanoic acid \\
\hline 14 & 23.697 & 6.26 & Chalepin \\
\hline 16 & 24.023 & 6.91 & 1,3,5(10)-Estratrien-3,17.beta,-diol, 17-acetate(ester) \\
\hline & 24.400 & 2.14 & 5-Hydroxymethyl-1,1,4a-trimethyl-6-methylenedecahydronaphtl
\end{tabular}

\section{Estimation of carbohydrate}

Estimation of carbohydrates was done on different plant samples and its standard graph was prepared using glucose at $490 \mathrm{~nm}$ absorbance (Fig. 7). The highest amount of carbohydrates were present in $A$. vasica with $139 \pm 0.20 \mathrm{mg}$ in $1 \mathrm{~g}$ of plant sample. $P$. pubinervius exhibited less amount of carbohydrate (85 $\pm 0.15 \mathrm{mg} / \mathrm{g}$ of plant sample taken) (Fig. 8).

\section{Estimation of flavonoid}

Flavonoid was estimated from the selected plant samples using quercetin as standard in $\mu \mathrm{g} / \mathrm{ml}$ with absorbance at $415 \mathrm{~nm}$ (Fig. 9). The highest amount of flavonoids were present in P. curviflorus with $105.32 \pm$ $0.75 \mathrm{mg} / \mathrm{g}$ of plant sample and the least amount of flavonoids were found in $R$. tuberosa with $25.68 \pm 0.03$ $\mathrm{mg} / \mathrm{g}$ of crude extract of plant sample taken (Fig. 10).

\section{GC-MS analysis}

The results of GC-MS analysis of the methanolic leaf extracts of $P$. thyrsiflorus showed the presence of various compounds such as 2-Ethylhexane, Decade, Dodecane, Tetradecane, Nonadecane, Hexanoic acid, 2ethythexyl ester, 2,4-Dimethyl-3-hexanone, Neophytadiene, n-Hexadecanoic acid, Phytol, Linoelaidic acid, 9,12,15-Octadecatrienoic acid, (Z,Z,Z)-, Octadecanoic acid, Chalepin, 1,3,5(10)-Estratrien3,17.beta,-diol, 17-acetate(ester) and 5-Hydroxymethyl1,1,4a-trimethyl-6-methylenedecahydronaphtl. There were sixteen peaks with sixteen different phytochemical compounds identified and the composition determined for this plant extract corresponded to $100 \%$ of the entire GC-MS chromatogram (Fig. 11; Table 2).

The GC-MS analysis of methanolic leaf extracts of P. pubinervius lead to the identification of Tetradecane, Neophytadiene, 2-Pentadecanone, 6,10,14-trimethyl-, Hexadecanoic acid, methyl ester, n-Hexadecanoic acid, Phytol, 9,12-Octadecadienoic acid (Z,Z)-, 7Tetradecenal, (Z)-, Squalene, 1,5-Cyclodecadiene and 1,5-dimethy1-8-(1-methylethylidene)-, (E,E). In the 


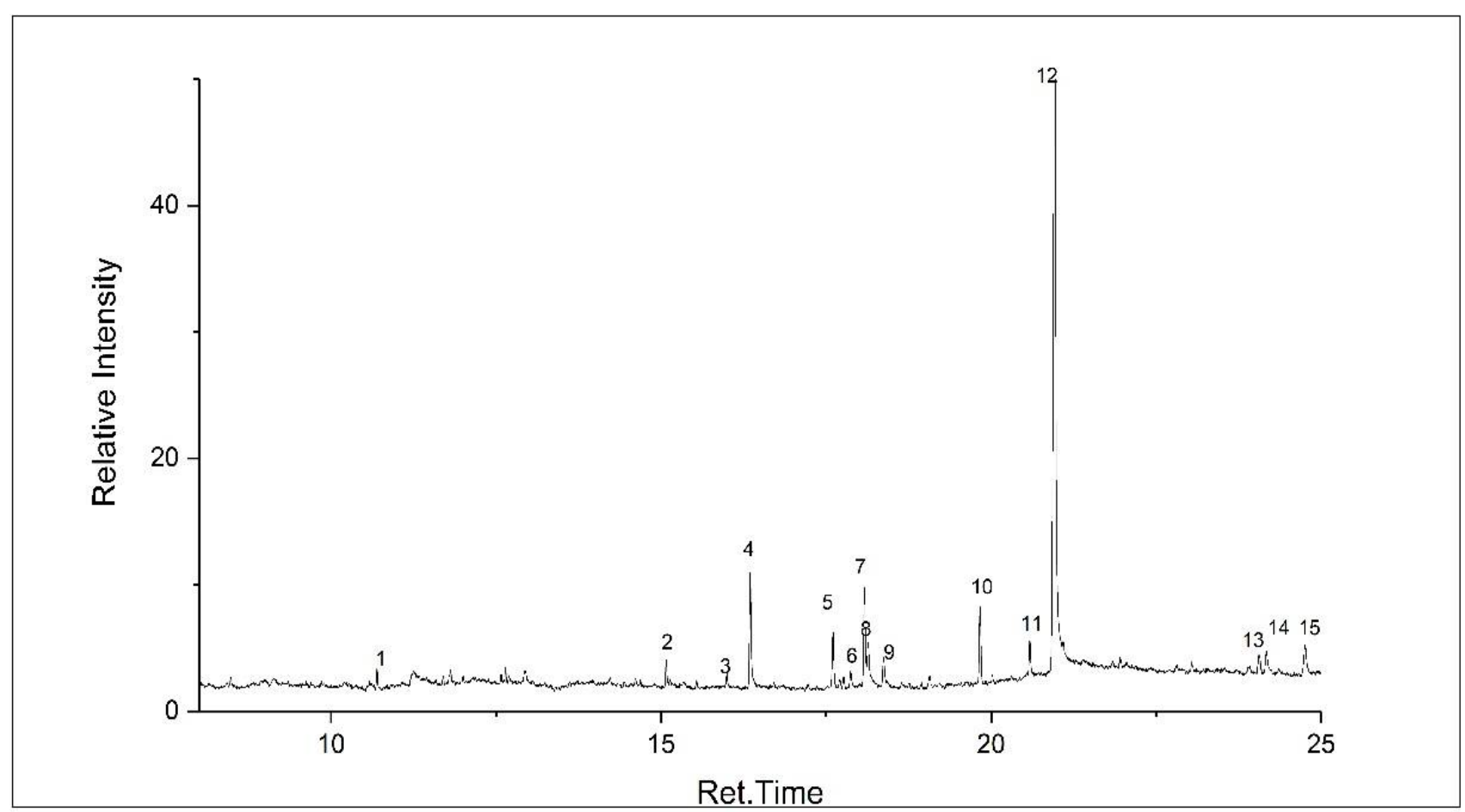

Fig. 12. GC-MS chromatogram of Phlogacanthus pubinervius. The phytochemical compounds identified in the methanolic extract in GC-MS is given in Table 3 with respect to the peaks.

Table 3. Compounds identified in the methanolic leaf extract of Phlogacanthus pubinervius in GC-MS

\begin{tabular}{rrrl}
\multicolumn{1}{c}{ Peak\# } & \multicolumn{1}{c}{ R. Time } & \multicolumn{1}{c}{ Area\% } & Name \\
\hline 1 & 10.696 & 1.69 & Tetradecane \\
\hline 2 & 15.083 & 3.52 & Neophytadiene \\
\hline 3 & 15.137 & 1.55 & 6,10,14-Trimethylpentadecan-2-one \\
\hline 4 & 16.000 & 2.49 & Hexadecanoic acid, methyl ester \\
\hline 5 & 16.356 & 14.57 & n-Hexadecanoic acid \\
\hline 6 & 17.872 & 10.76 & Phytol \\
\hline 7 & 18.076 & 2.33 & 9,12-Octadecadienoic acid (Z,Z) \\
\hline 8 & 18.139 & 6.67 & 7-Tetradecenal, (Z) \\
\hline 9 & 24.069 & 49.51 & Squalene \\
\hline 10 & 25.441 & 6.91 & 1,5-Cyclodecadiene, 1,5-dimethy1-8-(1-methylethylidene)-, (E,E)
\end{tabular}

present analysis ten phytocompounds were identified (Fig. 12; Table 3).

Phytochemical compounds such as Tetradecane, Neophytadiene, 2-Pentadecanone, 6,10,14-trimethyl-, Hexadecanoic acid, methyl ester, n-Hexadecanoic acid, Phytol, 9,12-Octadecadienoic acid (Z,Z)-, 7Tetradecenal, (Z)-, Squalene, 1,5-Cyclodecadiene, and 1,5-dimethy1-8-(1-methylethylidene) were identified in the methanolic leaf extracts of $P$. curviflorus in GC-MS. This leaf extracts were also showed the presence of ten phytochemical compounds in the GC-MS analysis (Fig. 13; Table 4).

2-ethyhexane, Undecane, Dodecane, Tetradecane, Nonadecane, 2,4-Di--tert-butylphenol, Phthalic acid, ethyl pentadecyl ester, Nonadecane, 1-Nonadecene, Neophytadien.e, 3,7,11.15, Tetrameihy1-2-hexadecen1-ol, 1,2-Benzenedicarboxylic acid, bis(2-methylpropyl) ester, Hexadecanoic acid methyl ester, n-Hexadecanoic acid, 9,12,15-Octadecattienoic acid methyl ester, (Z,Z,Z)-, $\quad 3,7,11,15-T e t r a m e t h y 1-2-h e x a d e c e n-1-o l$, Linoelaidic acid, 9,12,15, Octadecatrienoic acid, (Z,Z,Z)-, and Octadecanoic acid were identified in the GC-MS analysis of the leaf extracts of Ruellia tuberosa. This plant extract showed the presence of 19 compounds (Fig. 14; Table 5).

The results of GC-MS analysis of the methanolic leaf extracts of $A$. vasica showed the presence of bioactive compounds like 2-ethyhexane, Decane, Dodecane, Tetradecane, 2,4-Di-tert-butylphenol, 1Tridecene, Nonadecane, 1-Tricosene, 2Methyltetracosane, Neophytadiene, l Hexadecanoic acid, methyl ester, n-Hexadecanoic acid, $1 \mathrm{H}-$ Pyrrolo[2,1-b]quinazolin-9-one, 3-hydroxy-2,3dihydro-, 8,11,14-Eicosatrienoic acid, methyl ester, Phytol, Linoelaidic acid, 8,11,14-Eicosatrienoic acid, (Z,Z,Z)-, Octadecanoic acid, Squalene, and gamma.Sitosterol. This plant extract showed the presence of 20 compounds. More number of phytochemical compounds were found in this plant when compared to other plants studied in the present investigation (Fig. 15; Table 6).

\section{Antioxidant activity using DPPH}

The percentages of DPPH scavenging against the concentration of samples were plotted. The concentration of the samples required to decrease the 


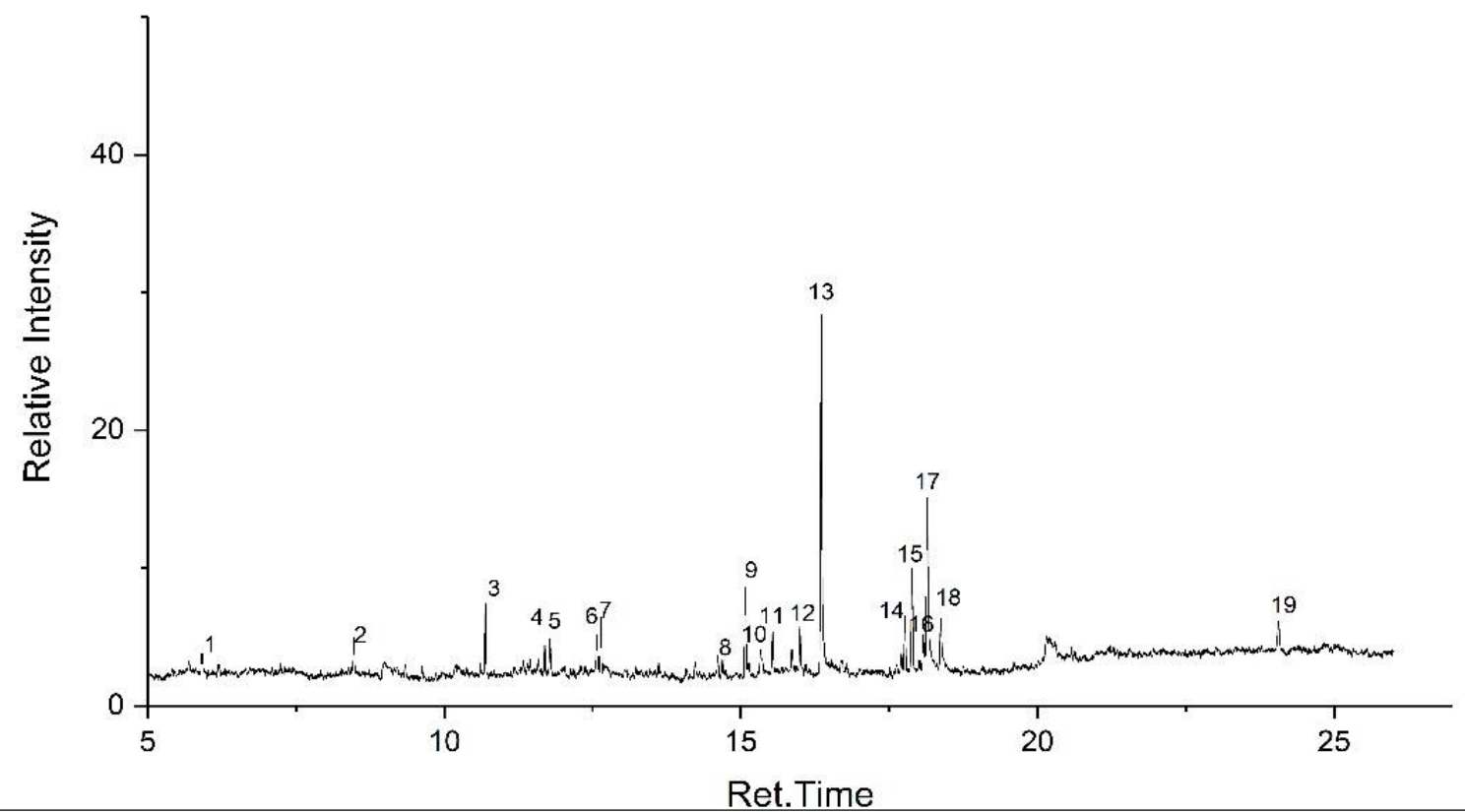

Fig. 13. GC-MS chromatogram of Phlogacanthus curviflorus. The phytochemical compounds identified in the methanolic extract in GC-MS is given inTable 4 with respect to the peaks.

Table 4. Compounds identified in the methanolic leaf extract of $P$. curviflorus in GC-MS

\begin{tabular}{cccl}
\hline Peak\# & R.Time & Area\% & Name \\
\hline 1 & 10.696 & 1.69 & Tetradecane \\
\hline 2 & 15.083 & 3.52 & Neophytadiene \\
\hline 3 & 15.137 & 1.55 & $6,10,14$-Trimethylpentadecan-2-one \\
\hline 4 & 16.000 & 2.49 & Hexadecanoic acid, methyl ester \\
\hline 5 & 16.356 & 14.57 & n-Hexadecanoic acid \\
\hline 6 & 17.872 & 10.76 & Phytol \\
\hline 7 & 18.076 & 2.33 & 9,12-Octadecadienoic acid (Z,Z) \\
\hline 8 & 18.139 & 6.67 & 7-Tetradecenal \\
\hline 9 & 24.069 & 49.51 & Squalene \\
\hline 10 & 25.441 & 6.91 & 1,5-Cyclodecadiene, 1,5-dimethyl-8-(1-methylethylidene)-, (E,E) \\
\hline
\end{tabular}

DPPH concentration by $50 \%$ was estimated by the interpolation from linear regression analysis and denoted $\mathrm{IC}_{50}$ value $(\mu \mathrm{g} / \mathrm{ml})$. P. pubinervius (77.83\%), $A$. vasica (74.81\%), $P$. curviflorus $(94.20 \%)$, and $R$. tuberosa $(70.78 \%)$ have shown highest antioxidant activity of DPPH-scavenging at $150 \mu \mathrm{g} / \mathrm{ml}$ of methanol extract comparing with the ascorbic value percentage of $(98.81 \%)$ (Table 3). $P$. thyrsiflorus (93.95\%), Oenanthe javanica (94.45\%) and Enydra fluctuans (93.45\%) have shown highest percentage when $100 \mu \mathrm{g} /$ $\mathrm{ml}$ of methanol crude sample extract was taken comparing with ascorbic value percentage of (97.53\%) (Table 7). DPPH scavenging activity at $150 \mu \mathrm{g} / \mathrm{ml}$ was more suitable than 100 or $250 \mu \mathrm{g} / \mathrm{ml}$ (Table 7) and showed more antioxidant property when compared with ascorbic acid.

\section{Statistical analysis}

The statistical analysis was carried out by evaluating the lack of fit, coefficient of regression $\left(\mathrm{R}^{2}\right)$ and the Fisher test value (F-value) obtained from the analysis of variance (ANOVA) considering $\mathrm{P}<0.05$ as significant using the software SPSS (Table 8). Three-dimensional response plots were generated by keeping one response as dependant variable and plotting it against two factors (independent variables). Statistical analysis clearly showed that there were no significant differences in the DPPH activity and the concentrations of phenol and flavonoids. The analysis indicated that in plant samples the percent of increase in DPPH activity were positively correlated with the increase in the concentration of phenols and flavonoids.

\section{Discussion}

The people in developing countries are very much depended on plants for their livelihood. The traditional herbal medicines play an important role in their health and in the treatment of many infectious diseases. The population of the rural areas are more exposed to traditional ways of treatment because of its easy availability and cheaper cost. Phytochemical screening is of very important in identifying the new sources of plant products which are therapeutically and industrially significant for its medicinal properties to make the best and judicious use of available natural wealth (15). The phytochemical screening of the extracts showed the presence of tannins, flavonoids, proteins, carbohydrates, phenol in methanolic extract of the plant materials. 


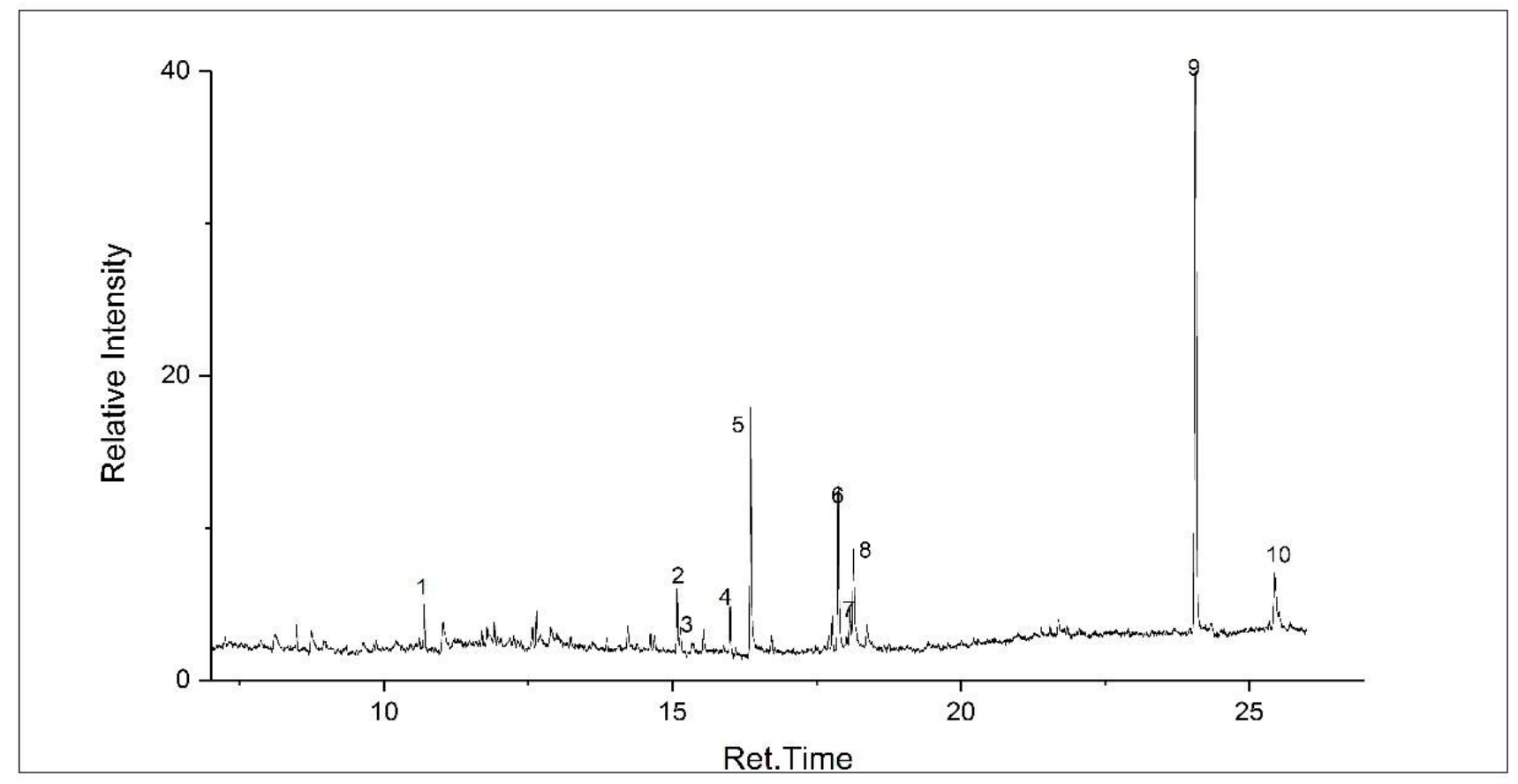

Fig. 14. GC-MS chromatogram of Ruellia tuberosa. The phytochemical compounds identified in the methanolic extract in GC-MS is given in Table 5 with respect to the peaks.

Table 5. Compounds identified in the methanolic leaf extract of $R$. tuberosain GC-MS

\begin{tabular}{cccl}
\hline \multicolumn{1}{c}{ Peak } & R. Tirne & Area $\%$ & Name \\
\hline 1 & 3.792 & 61.27 & 2-ethyhexane \\
\hline 2 & 5.916 & 0.65 & Undecane \\
\hline 3 & 8.477 & 0.87 & Dodecane \\
\hline 4 & 10.692 & 1.59 & Tetradecane \\
\hline 5 & 11.695 & 0.74 & Nonadecane \\
\hline 6 & 11.784 & 1.18 & 2.,4-Di--tert-butylphenol \\
\hline 7 & 12.575 & 0.97 & Phthalic acid, ethyl pentadecyl ester \\
\hline 8 & 12.641 & 1.2 & Nonadecane \\
\hline 9 & 14.613 & 0.55 & 1-Nonadecene \\
\hline 10 & 15.077 & 2.55 & Neophytadien.e \\
\hline 11 & 15.534 & 1.1 & $3,7,11.15-T e t r a m e i h y 1-2-h e x a d e c e n-1-o l$ \\
\hline 12 & 15.861 & 0.52 & 1,2-Benzenedicarboxylic acid, bis(2-methylpropyl) ester \\
\hline 13 & 15.996 & 1.05 & Hexadecanoic acid. methyl ester \\
\hline 14 & 16.355 & 10.98 & n-Hexadecanoic acid \\
\hline 15 & 17.764 & 1.6 & (Z,Z,Z)-9,12,15-Octadecatrienoic acid, methyl ester \\
\hline 16 & 17.886 & 3.33 & $3,7,11,15-T e t r a m e t h y 1-2-h e x a d e c e n-1-o l$ \\
\hline 17 & 18.08 & 1.02 & Linoelaidic acid \\
\hline 18 & 18.144 & 6.36 & Octadeca-9,12,15-trienoic acid \\
\hline 19 & 18.37 & 1.63 & Octadecanoic acid \\
\hline
\end{tabular}

The quantitative phytochemical analysis has revealed that $P$. thyrsiflorus contains a high amount of tannins. Tannins are phenol compounds with the benzene ring to which a hydroxyl group is attached. They are soluble in water and will precipitate alkaloids, nitrogenous bases and some glycosides when combined with other plant products in their powdered form. Tannins are often used to antidote alkaloid poisoning. This helps in pest prevention and attack of diseases on these plants. Total phenolic content in methanol extract as per our study showed high content in most of the samples but the highest amount was observed in $P$. thyrsiflorus. Phenols are reported as an essential plant compound because of their free radical scavenging ability due to their hydroxyl groups. Phenolic compounds may contribute directly to antioxidant action $(11,16)$.

Protein and carbohydrate estimation carried out in the plant samples can be related to maintaining stability and shelf life of the respective plant products. $P$. pubinervius had the highest protein content indicating that stability and shelf life is much well developed in Phlogacanthus while A. vasica had the high carbohydrate content.

From this study, it was concluded that the presence of various phytochemicals, mainly the flavonoids and phenols might be responsible for the 


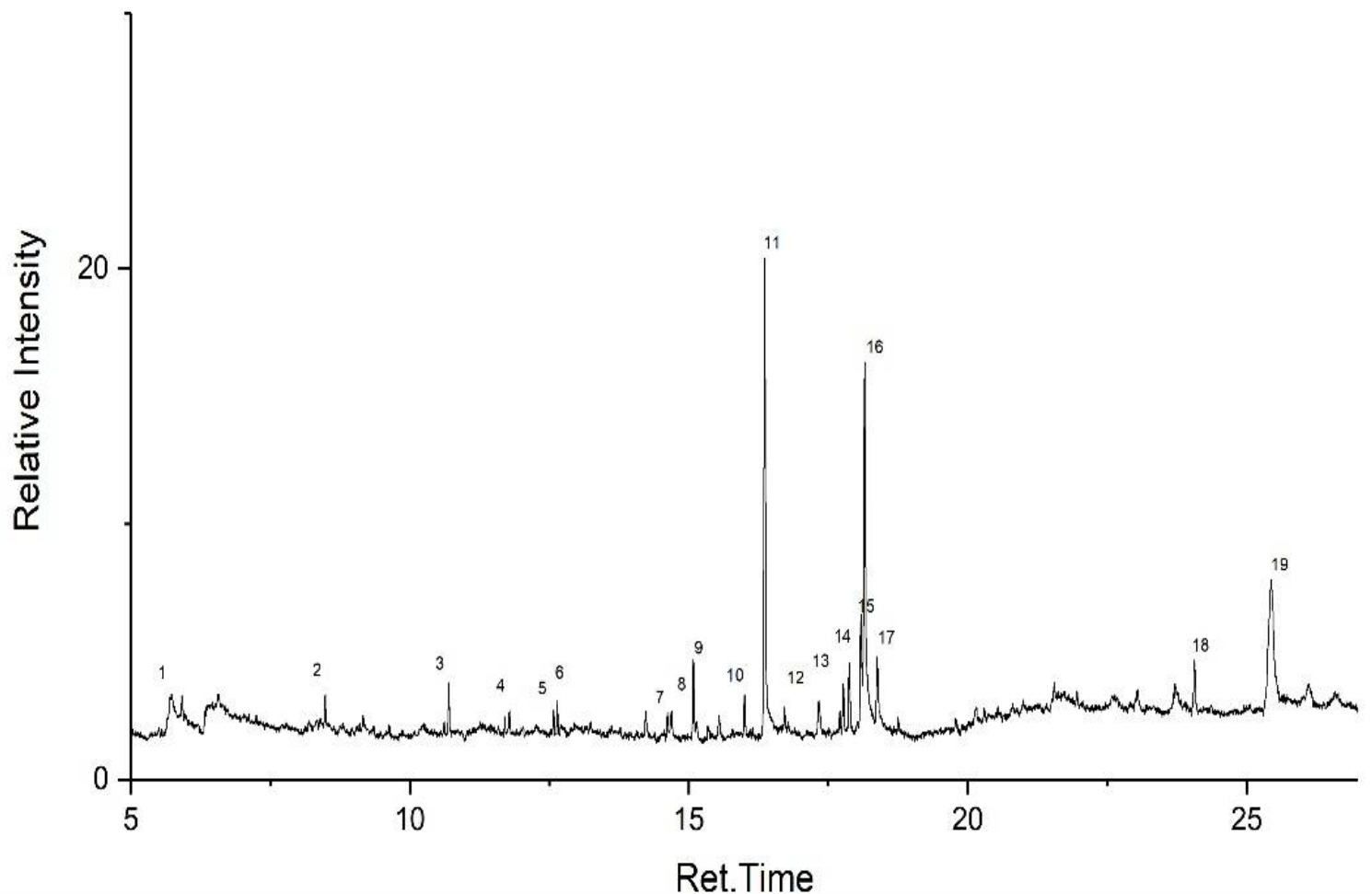

Fig. 15. GC-MS chromatogram of A. vasica. The phytochemical compounds identified in the methanolic extract in GC-MS is given in Table 6 with respect to the peaks.

Table 6. Compounds identified in the methanolic leaf extract of A. vasica in GC-MS

\begin{tabular}{cccl}
\hline Peak\# & R.Time & Area $\%$ & Chemical compounds \\
\hline 1 & 3.782 & 62.32 & 2-ethyhexane \\
\hline 2 & 5.918 & 0.44 & Decane \\
\hline 3 & 8.484 & 0.40 & Dodecane \\
\hline 4 & 10.697 & 0.66 & Tetradecane \\
\hline 5 & 11.788 & 0.76 & 2,4-Di-tert-butylphenol \\
\hline 6 & 12.577 & 0.30 & 1-Tridecene \\
\hline 7 & 12.645 & 0.39 & Nonadecane \\
\hline 8 & 14.617 & 0.43 & 1-Tricosene \\
\hline 9 & 14.690 & 0.55 & 2-Methyltetracosane \\
\hline 10 & 15.081 & 1.26 & Neophytadiene \\
\hline 11 & 15.999 & 0.71 & Hexadecanoic acid, methyl ester \\
\hline 12 & 16.360 & 8.99 & n-Hexadecanoic acid \\
\hline 13 & 17.331 & 0.97 & 2,3-Dihydro-3-hydroxypyrrolo(2,1-b)quinazolin-9(1H)-one hydrochloride \\
\hline 14 & 17.767 & 0.82 & 8,11,14-Eicosatrienoic acid, methyl ester \\
\hline 15 & 17.875 & 1.34 & Phytol \\
\hline 16 & 18.087 & 2.36 & Linoelaidic acid \\
\hline 17 & 18.150 & 8.68 & 8,11,14-Eicosatrienoic acid \\
\hline 18 & 18.375 & 1.42 & Octadecanoic acid \\
\hline 19 & 24.061 & 1.01 & Squalene \\
\hline 20 & 25.436 & 6.18 & Clionasterol (Gamma-Sitosterol) \\
\hline
\end{tabular}

free radical scavenging activity of the selected plants pointing to their use as a potential source of natural antioxidant for the treatment of free-radical and agerelated diseases. In the present scenario, the study of antioxidants has got very significant role because of its health benefits. The antioxidants belong to a diverse group of chemical compounds which act as a protection to the body from oxidative damage induced by free radicals and reactive oxygen species by suppressing their formation acting as scavengers and acting as their substrate (14). The best known natural antioxidants include hydrophilic compounds like vitamin $\mathrm{C}$, thiols and flavonoids; and lipophilic compounds, i.e., vitamin $\mathrm{E}$, vitamin $\mathrm{A}$, and carotenoids. Because of the complex nature of phytochemical extracts of plants, which contain different functional groups, polarity and chemical behaviour, it could lead to scattered results, depending on the test employed (16). The DPPH free radical scavenging assay is one of the most widely used methods to evaluate antioxidant activity of plant extracts. In the presence of an antioxidant, DPPH radical form a stable molecule by gaining one more electron or hydrogen atom from the 
Table 7. Percentage of DPPH scavenging activity shown in different plant sample extracts of methanol in different concentrations

\begin{tabular}{lccc}
\hline \multicolumn{1}{c}{ Sample } & \multicolumn{2}{c}{ DPPH scavenging activity (\%) at different concentrations } \\
\cline { 2 - 4 } & $\mathbf{1 0 0} \mathbf{~ \mathbf { g } / \mathbf { m l }}$ & $\mathbf{1 5 0} \mathbf{\mu g} / \mathbf{m l}$ & $\mathbf{2 5 0} \boldsymbol{\mu g} / \mathbf{m l}$ \\
\hline Phlogacanthus pubinervius & $77.83 \pm 0.535$ & $57.93 \pm 1.135$ & $77.83 \pm 1.207$ \\
\hline Adhatoda vasica & $74.81 \pm 1.213$ & $42.56 \pm 1.300$ & $74.81 \pm 1.096$ \\
\hline Phlogacanthus thyrsiflorus & $92.94 \pm 0.970$ & $93.95 \pm 0.592$ & $92.94 \pm 2.484$ \\
\hline Phlogacanthus curviflorus & $94.2 \pm 0.529$ & $75.81 \pm 0.531$ & $94.2 \pm 3.078$ \\
\hline Ruellia tuberosa & $70.78 \pm 4.410$ & $35.76 \pm 1.559$ & $70.78 \pm 1.556$ \\
\hline
\end{tabular}

(Mean \pm standard deviation, $n=3$ )

Table 8. ANOVA Table showing the significant difference in DPPH scavenging activity between the different plant samples

\begin{tabular}{lcrrrr}
\hline Source & $\begin{array}{c}\text { Type III Sum of } \\
\text { Squares }\end{array}$ & df & Mean Square & F & Sig. \\
\hline Corrected Model & $4623.615^{\mathrm{a}}$ & 6 & 770.603 & 4.607 & .026 \\
\hline Intercept & 85152.282 & 1 & 85152.282 & 509.076 & .000 \\
\hline concentration & 1373.904 & 2 & 686.952 & 4.107 & $.059^{\mathrm{b}}$ \\
\hline plant samples & 3249.711 & 4 & 812.428 & 4.857 & $.028^{\mathrm{a}}$ \\
\hline Error & 1338.147 & 8 & 167.268 & & \\
\hline Total & 91114.044 & 15 & & & \\
\hline Corrected Total & 5961.762 & 14 & & & \\
\hline
\end{tabular}

${ }^{\text {a }}$ Statistically significant difference is observed if $\mathrm{P}<0.05$; ${ }^{\mathrm{b}}$ not statistically significant difference is observed if $\mathrm{P}>0.05$

antioxidant and the UV absorbance decreases which signifies the scavenging activity of natural products as well as synthetic compounds. Pourmorad et al. (17, 18) reported that extracts of Syzygium operculatus, Astilbe rivularis and Mallotus philippnensis showed potent radical scavenging activity with $\mathrm{EC}_{50}$ close to that of ascorbic acid. Lower $\mathrm{EC}_{50}$ value indicates higher antioxidant activity. A linear relationship between total phenol and antioxidant activity of plant species have been reported in many of the plant species and it is attributed to the scavenging ability of their phenolic hydroxyl groups $(15,16,19)$.

In the present study, antioxidant assays indicate that plant extracts showing higher antioxidant activity and higher phenol and flavonoid contents could be significant source of natural antioxidant, which might be helpful in preventing the progress of various oxidative stresses and its related disorders. The medicinal plants used in this study have showed potent antioxidant activity but there is limited scientific evidence on those plants. So, further study is to be conducted to prove their potency. Further investigation is to be carried out to isolate and identify the components responsible for the antoxidative activity that are currently unclear.

\section{Conclusion}

In the present study, $P$. thyrsiflorus had more phytochemical contents than any other selected plants from Acanthaceae. It has most content in phytochemicals, and the same has been used for cooking, medicinal, oral ingestion, etc on various purposes. The present study has revealed the presence of phytochemical compounds present in the plant extracts. All of these medicinal plants are useful in new drug development and in pharmacological industries and for the benefit of today's world. However, there are many species of genus Phlogacanthus that are important and not fully recorded. With the ongoing research on these plants, it may be successful in finding out suitable compatible medicines from all these medicinal plants and thus helpful in the future.

\section{Authors' contributions}

Both authors have made a significant scientific contribution to the research described in the manuscript. Both authors performed the experiment, analysed the data and wrote the manuscript.

\section{Acknowledgements}

The study was supported by CHRIST (Deemed to be University) and we are grateful to the management and faculty of CHRIST (Deemed to be University), Bengaluru for their unconditional support and encouragement.

\section{Conflicts of Interest}

The authors declares that they have no competing interests.

\section{References}

1. Phurailatpam A, Singh S, Chanu T, Ngangbam P. Phlogacanthus - An important medicinal plant of North East India: A review. Afr J Agric Res. 2014;9(26):2068-72. https://doi.org/ 10.5897/AJAR2013.8134

2. Laitonjam WS, Yumnam RS, Kongbrailatpam BD. Phytoconstituents of Phlogacanthus pubinervius Nees: Leaves and their free Radical Scavenging Activities. Nat Prod Journal. 2013;2(4):287-92. https://doi.org/10.2174/2210315511202040287

3. Gangwar AK, Ghosh AK. Medicinal uses and Pharmacological activity of Adhatoda vasica. Int J Herb Med. 2014;2(1):88-91

4. Karthikeyan A, Shanthi V, Nagasathaya A. Preliminary phytochemical and antibacterial screening of crude extract of the leaf of Adhatoda vasica L. Int J Green Pharm. 2009;3(1):78. https://doi.org/10.4103/0973-8258.49381

5. Singh TP, Singh OM, Singh HB. Adhatoda vasica Nees: A review on its phytochemical and pharmacological profile. Nat Prod J. 2011;1(1):29-39. https://doi.org/10.2174/2210316311101010029 
6. Saikia D, Baruah PS, Hasnu S, Nath S, Akhtar S. Phytochemical screening and antioxidant activity of leaf extract of Phlog acanthus thyrsiflorus Nees. - a medicinal plant of Assam, India. Biosci Discov. 2018;9(2):237-43

7. Kumar A, Bidyapani T, Digvijay S, Sharma NR, Mohan A. Study of phytochemical compositions of leaves extracts of Phlogacanthus thyrsiformis, its antibacterial and silver nanoparticle derived cell cytotoxicity on HeLa cell line. J Pharm Res. 2017;11(12):1513-17

8. Dutta B, Borthakur SK. A new variety of Phlogacanthus curviflorus (Wall.) Nees from Assam, India. Bangladesh J Plant Taxon. 2016;23(1):71-74. https://doi.org/10.3329/bjpt.v23i1.28347

9. Chothani DL, Patel MB, Mishira SH, Vaghasiya HU. Review on Ruellia tuberosa (cracker plant). Pharmacogn J. 2010;2(12): 50612. https://doi.org/10.1016/S0975-3575(10)80040-9

10. Samkeliso T, Fanyana M, Michael P. Analysis of the phytochemical contents and antioxidant activities of crude extracts from Tulbaghia species. J Tradit Chin Med. 2018;38(2): 272-79. https://doi.org/10.1016/j.jtcm.2018.04.005

11. Jyoti JJ, Dylan DS, Saji V, Jobi X, Paari KA. Drinking straw from coconut leaf: A study of its epicuticular wax content and phenol extrusion properties. Asian J Plant Sci. 2019;18(3):13947. https://doi.org/10.3923/ajps.2019.139.147

12. Sadasivam S, Manickam A. Biochemical Methods Delhi: New Age International publisher; 1996
13. Chang CC, Yang MH, Wen HM, Chern JC. Estimation of total flavonoid content in Propolis by two complementary colorimetric methods. J Food Drug Anal. 2002;10(3):178-82

14. Subedi L, Timalsena S, Duwadi P, Thapa R, Paudel A, Parajuli K. Antioxidant activity and phenol and flavonoid contents of eight medicinal plants from Western Nepal. J Tradit Chin Med. 2014;34(5):584-90. https://doi.org/10.1016/S0254-6272(15)30067-4

15. Blois MS. Antioxidant determinations by the use of a stable free radical. Nature. 1958;181:1199-200. https://doi.org/ 10.1038/1811199a0

16. Jobi X, Jayaram R. A study on antioxidant and antibacterial activities of the fruit and seed extracts of two different cultivars of Momordica charantia Linn. J Pharmacogn Phytochem. 2017;6(6):1182-87. https://doi.org/10.22161/ijeab/2.6.13

17. Salvayre AN, Dousset N, Ferretti G, Bacchetti T, Curatola G, Salvayre R. Antioxidant and cytoprotective properties of highdensity lipoproteins in vascular cells. Free Radic Biol Med. 2006;41(7):1031-40. j.freeradbiomed.2006.07.006 https://doi.org/10.1016/

18. Vinson JA, Su X, Zubik L, Bose P. Phenol antioxidant quantity and quality in foods: fruits. J Agric Food Chem. 2001;49(11): 5315-21. https://doi.org/10.1021/jf0009293

19. Pourmorad F, Hosseinimehr HJ, Shahabimadj N. Antioxidant activity, phenol and flavonoid contents of some selected Iranian medicinal plants. Afr J Biotechnol. 2006;5(11):1142-45. https://doi.org/10.1021/jf0009293 